\section{Country of origin effect: a study with Brazilian consumers in the luxury market}

\author{
Maria Gabriela Montanari † \\ FEA-RP/USP, Ribeirão Preto, SP, Brazil \\ Jonny Mateus Rodrigues $\Omega$ \\ FEA-RP/USP, Ribeirão Preto, SP, Brazil \\ Janaina de Moura Engracia Giraldi ${ }^{¥}$ \\ FEA-RP/USP, Ribeirão Preto, SP, Brazil \\ Marcos Fava Neves * \\ FEA-RP/USP, Ribeirão Preto, SP, Brazil
}

\section{ABSTRACT}

This study aimed to verify the extent of the influence of the country of origin in the decision to purchase a product when considering a number of other attributes such as brand, price, warranty and store. In order to verify this country of origin effect, we conducted an empirical study in which 329 Brazilian students used and evaluated three luxury brands from three different nations. From statistical analyses, we concluded that the country of origin is the criterion of minor importance in the purchase decision of a luxury perfume, while the fragrance, the price, and the brand are the most important cues in this purchase. The study provides indications that corroborate the hypothesis that marketing managers should direct their marketing efforts mainly to premium price and symbolism, history and strength of the brand, leaving aside some strategies that emphasize the country of origin of the brand.

Keywords: Country of Origin Effect. Luxury Brands. Brand.

\section{INTRODUCTION}

One of the oldest and most persistent concerns of international marketing is whether the origin of a product makes it more or less preferable to consumers (KOSCHATE-FISCHER; DIAMANTOPOULOS; OLDENKOTTE, 2012).

In this way, the country of origin is seen as extrinsic information that influences the evaluations of products and their quality (PAPPU; QUESTER; COOKSEY, 2005), and consumers' willingness to pay (KOSCHATE-FISCHER; DIAMANTOPOULOS; OLDENKOTTE, 2012). The country of origin influences on quality perceptions, product evaluations, and consumer intentions and is termed as the country of origin effect.

This effect has direct implications on marketing strategies, such as the usage of the term "made in" for many brands and products in order to identify the source of the product and to create associations in the consumers' minds (SCHULTZ; JAIN, 2015). Moreover, marketing managers use the countries' image to develop unique selling propositions in which they project a rich set of symbolisms and country images onto the products (BRIJS; BLOEMER; KASPER, 2011).

However, the relevance of this topic is being widely discussed, especially considering multinational production, global branding,
Corresponding author:

${ }^{\dagger}$ FEA-RP/USP, Ribeirão Preto, SP, Brazil E-mail: mariagabrielamontanari@yahoo.com.br

${ }^{\Omega}$ FEA-RP/USP, Ribeirão Preto, SP, Brazil E-mail: jonnymateus@usp.br

${ }^{¥}$ FEA-RP/USP, Ribeirão Preto, SP, Brazil E-mail: jgiraldi@usp.br

* FEA-RP/USP, Ribeirão Preto, SP, Brazil

E-mail: favaneves@gmail.com

Received: 04/04/2017.

Revised: 05/04/2017.

Accepted: 06/19/2017

Published Online: 06/14/2018

DOI: http://dx.doi.org/10.15728/bbr.2018.15.4.3 
decline of the labeling rules of the country of origin and the fact that many consumers are unaware of the origin of the products they buy (USUNIER, 2006). However, consumers often uses the country of origin to evaluate the product in the absence of other information (USUNIER, 2011), but when they have access to more cues, the influence of the country of origin can be reduced (CHAO; RAJENDRAN, 1993).

At this point, the luxury market can be used for the purpose of verifying the country of origin effect, since it is growing in scope and in the number of consumers (KIM; KO, 2012), highlighting the increasing demand in emerging countries (KAPFERER, 2014).

The segment has become global, with several recognized and internationalized brands (KAPFERER, 2014, GODEY et. al, 2012), and uses strategies based on the country of origin as in the case of Chanel, which has in its perfume bottles the word "Paris" referring to France. In addition, when a consumer makes decisions regarding the purchase of a luxury brand, they consider a series of attributes such as price, quality, beauty, rarity, an inspiring brand and status (JACKSON, 2004; GODEY et al., 2012), in addition to the country of origin itself.

Thus, the objective of this research was to show the extent of the influence of the country of origin in the decision to consume luxury brands when considering a number of other attributes such as brand, price, warranty and store. In order to do this, we conducted a study with Brazilian consumers regarding three luxury perfume brands from three different countries.

This analysis contributes with evidence to marketing managers about the main criteria taken into account by Brazilian consumers when purchasing a luxury perfume brand and, if the country of origin is important in this decision, then marketing efforts can be directed in order to delineate brand strategies in terms of price, communication, and distribution for these perfumes. It is very important to explore the impact of the country of origin on the perception of luxury brand so that companies know which strategy to apply: emphasize the country of origin or move away from it (KRUPKA; OZRETIC-DOSEN; JOZO PREVISIC, 2014).

For the country of origin emphasis to become successful, it is necessary that governments and marketers carry out the so-called place branding, in which the focus is business and marketing for places (HANNA; ROWLEY, 2008), that is, it is characterized by the effort to use strategies developed in the commercial sector to manage the power of a place (HAM, 2008). These strategies should be able to capture and articulate the distinct characteristics about a place and be a tool that allows places to express their cultural particularities and to form the place identity (KAVARATZIS; HATCH, 2013). This identity influences the images that the place has, as well as its reputation, which, according to Ham (2008), directly affects consumer's purchasing decisions. Therefore, if the country of origin is important and has a positive effect on the perception of the luxury brand, the techniques associated with place branding should work to strengthen this image and may even create new positive associations that can be extended to other product categories.

In addition, luxury brand marketing efforts have traditionally focused on developed nations as they encompass most consumer demand (SCHULTZ; JAIN, 2015); however, emerging countries are becoming increasingly open to luxury brands, gradually increasing the interest of brand managers (KRUPKA; OZRETIC-DOSEN; PREVISIC, 2014), since they need to understand the motivations of these consumers to purchase luxury brands in these countries.

From the theoretical point of view, this research contributes to the country of origin literature, discussing its possible influence on consumers in relation to other attributes (brand, price, warranty and store), in the context of luxury which, according to Shukula (2011), has received considerable interest amongst academics, and in the context of emerging countries, which has drawn increasing attention. 
We based the literature review for this study on the following topics: country of origin effect, moderators of the country of origin effect, and luxury brands.

\subsection{COUNTRY OF ORIGIN EFFECT}

Studies addressing the country of origin area have essentially risen to determine whether the country of origin of a product influences its evaluations by consumers and consequently their purchasing decisions (ZEUGNER-ROTH; DIAMANTOPOULOS, 2010), which is the so-called country of origin effect.

This effect implies a differential consumer response to a product, as the country is perceived as the source of this product (ANDINA; GABRIELA; ROXANA-DENISA, 2015 ), that is, it plays an important role in consumers' purchasing decision, since companies remain associated with their countries of origin (HAM, 2008).

Consumers, whether consciously or subconsciously, incorporate a stimulus from the country of origin (e.g. the label "made in") as an evaluative criterion in the formation of their attitudes towards a product (BLOEMER; BRIJS; KASPER, 2009). Thereby, "German cars", "Japanese electronics", and "French wines" are evaluated differently from "Italian cars", "Taiwanese electronics", and "Greek wines" (APIL; KAYNAK, 2010) due to the fact that the image and political and commercial reputation of the countries or state interact with the country of origin effect (HAM, 2008). This may have implications for the determination of marketing strategies and actions by companies and governments (NAGASHIMA; 1970; LAROCHE et. al, 2005).

Despite the large number of studies in the literature, the theoretical utility and practical relevance of the country of origin construct have been criticized (HERZ; DIAMANTOPOULOS, 2013) and, consequently, the country of origin effect on the consumer's behavior as well.

In this context, Prendergast, Tsang and Chan (2010) argue that perhaps what compromises the relevance of the country of origin is the separation between the country where the product is produced and the country of the product brand. That is so because today, the brand of a product can exist and be managed in country $\mathrm{X}$, but in can be produced in country $\mathrm{Y}$ or $\mathrm{Z}$, due to lower labor and operating costs, for example. Therefore, Samiee (2010) suggests the use of the term brand origin (BO).

Another point worth of discussion, is that researchers have recently begun to argue that consumers attach little importance to the country where the product is made (KABADAYI; LERMAN, 2011) and often do not recognize the correct country of origin of many wellknown brands (HERZ; DIAMANTOPOULOS, 2013).

At this point, Samiee (2010) and Usunier (2011) point out that focus has shifted from the country of production to the emphasis on the country from which the product brand originates. That focuses mainly on the consumer's need to recognize the brand's origin, and how corporate managers can manipulate the information of the brand's origin in order to create or maintain positive associations between the country and the product/brand.

According to Bhaskaran and Sukumaran (2007), there are many studies that do not consider the existence of a country of origin effect, that is, the country of origin has no relevance and it does not influence the attitudes, behaviors, and choices of consumers; and therefore, it is not a relevant factor. This is strengthened by the fact that in surveys conducted when the country of origin is used as an informational cue, only a small proportion of respondents indicate this factor as having an important role in consumer's choice (HERZ; DIAMANTOPOULOS, 2013).

However, it is worth emphasizing that consumers often try to look rational, and the survey may not be appropriate to assess the country of origin effect. Therefore, an approach 
with experiments may be more adequate. In addition, there is no consensus on this issue, and research on country of origin is still considered important for marketing (KABADAYI; LERMAN, 2011), since several studies emphasize the importance of the country of origin effect (KOSCHATE-FISCHER; DIAMANTOPOULOS; OLDENKOTTE, 2012).

What is being discussed is in which situations this effect is bigger or smaller. In this sense, a point discussed is that once consumers have greater access to information and variables to decide, the country will have less expected influence in the product evaluations by these consumers (CHAO; RAJENDRAN, 1993). It is also debated, as to what situations the well-known brand overlaps with the origin of the country. Therefore, the moderators of this country of origin effect should be understood, that is, the factors that influence the extent of this effect will be discussed below.

\subsection{MODERATORS OF THE COUNTRY OF ORIGIN EFFECT}

Despite the numerous attempts to measure the country of origin effect and the evidence of its existence being pointed out by several studies, using different methods, products, and countries, there are still doubts about their magnitude. It is believed that there are several factors that can increase or decrease this effect.

Therefore, the country of origin effects on the evaluations of products by the consumer can be moderated by a variety of intrinsic and extrinsic cues about the product (GIRALDI; CARVALHO, 2009).

Intrinsic cues are related to the inherent traits of the products such as ingredients that cannot be modified without changing physical attributes: weight, taste, performance, potency, composition (materials), temperature, and product durability (AYROSA, 1998; BLOEMER; BRIJS, KASPER, 2009; CHAO; RAJENDRAN, 1993; SCHULTZ; JAIN, 2015; USUNIER, 2006).

Regarding this information, we know to begin with that consumers make rational choices on products by comparing and contrasting their various attributes (AHMED et al., 2013). In this way, products with different physical characteristics will have different evaluations. The country of origin effect then varies among the various product categories (APIL; KAYNAK, 2010; D’ASTOUS; AHMED, 1999). Considering the luxury perfume category, we believe that the perfumes will be evaluated in a similar way, because, although the brands are different, the consumer considers the same intrinsic and extrinsic cues to compare and evaluate them. Hence, we are able to develop the first research hypothesis considering the context of luxury brands:

\section{HyPothesis 1. THE DIFFERENCES BETWEEN THE CUES EVALUATIONS OF LUXURY BRANDS OF THE SAME CATEGORY WILL NOT BE SIGNIFICANT.}

Moreover, we perceive intrinsic cues as more accurate indicators of product quality than extrinsic ones, thus having a more powerful effect on quality judgments (OLSON; JACOBY, 1972). In this regard, a research has shown that consumers rely more on the intrinsic characteristics of the product while forming their opinions (GODEY et al., 2012).

On the other hand, extrinsic cues are related to the product but if they change, they do not directly affect it, covering the price, brand, product warranty, store, and country of origin (AYROSA, 1998; BILKEY; NES, 1982; BLOEMER; BRIJS, KASPER, 2009; CHAO; RAJENDRAN, 1993; DEB; CHAUDHURI, 2012; KAYNAK; KUCKUKEMIROGLU; HYDER, 2000; SCHULTZ; JAIN, 2015; USUNIER, 2006).

The country of origin, as an extrinsic cue, has a limited influence on product quality perceptions (BILKEY; NES, 1982). In many situations, consumers are unaware of the origin of the products they buy and, if they know it, they use it in combination with other information cues such as price, brand, and retail store image (USUNIER, 2006). 
BBR

15,4

In some situations, the brand replaces information about the country of origin, through the association of brand names with the countries (BHASKARAN; SUKUMARAN, 2007). In other situations, the brand suggests the country of origin (USUNIER, 2011).

Thus, "the country of origin is one factor affecting the product's acceptance or rejection among several evaluative criteria considered when purchasing or evaluating foreign made products" (KAYNAK; KUCKUKEMIROGLU; HYDER, 2000, p. 1226). A more favorable country of origin with a positive image generates good product evaluations by consumers, but the importance of this information cue in the evaluation depends on the amount of information available on the products. When other external cues are used, the country of origin effects are weakened (KABADAYI; LERMAN, 2011). Based on this statement and considering perfumes as the focus of the research, we are able to delineate the following hypothesis:

\section{HYPOTHESIS 2. THE COUNTRY OF ORIGIN RELEVANCE IN THE BRAND EVALUATION OF LUXURY PERFUMES IS SMALLER IN THE PRESENCE OF OTHER EXTRINSIC CUES: BRAND, PRICE, WARRANTY AND STORE.}

This hypothesis is reinforced by some studies in the luxury market. Godey et al. (2012), for example, show that the country of origin's relevance is lower than the brand in luxury goods, and that the companies should emphasize the design, brand, and warranty criteria in their marketing strategies, although there are differences between countries regarding the importance of each of these criteria. At this point, this research closely resembles the one conducted by Godey et al. (2012), but here the focus is to highlight a specific country, Brazil, which has a large number of consumers that can be pursued by luxury brands managers. Despite being an emerging country, the demand of the luxury market is growing and it should be understood in more depth.

Furthermore, Pizzzinatto et al. (2014) point out that the strength of a luxury brand is independent of the manufacturing country of origin. Contrary to expectations, a luxury brand does not benefit from the country of origin's positive effect. This phenomenon is verified only in the evaluation of non-luxury brands.

Schultz and Jain (2015) state that country of origin effects are not present in the purchase intention and in the luxury brand purchasing situation. Krupka, Ozretic-Dosen and Previsic (2014) argue that the perception of the country of origin of the brand has an impact on the luxury perception of the brand, but if the country of origin perceived is strongly linked to luxury - as in the case of Italy —, it does not matter where the product is actually originated or manufactured.

The brand itself implies the existence of a powerful "history", making the country of origin less important in the case of well-known brands (KRUPKA; OZRETIC-DOSEN; PREVISIC, 2014), that is, the country of origin effect should be reduced with popular brands (AHMED et al., 2004), as in the case of luxury brands known by consumers worldwide. Strong brands can reverse the country of origin effect and compensate for the negative country's image (CASTRO, GIRALDI, 2012).

The country of origin matters when consumers evaluate products with low involvement, but when there are other extrinsic cues (price and brand) and high involvement, the country of origin effect is weaker and the brand becomes the determinant factor (AHMED et al., 2004). The decision to purchase a luxury perfume can thus be considered as high involvement, which would be associated with the little importance of the country of origin, and therefore to a weak country of origin effect. 
In addition to the brand, price may also overlap the country of origin in terms of importance, as shown by D'Astous and Ahmed (1999). However, lower prices can be used to mitigate this negative country of origin effect, as highlighted by Apil and Kaynak (2010).

Thus, the question is to what extent other cues, such as a well-known brand name, the product warranty or a supplier with a good reputation can compensate for negative information about the country of origin in evaluations of products (BILKEY; NES, 1982). The following topic is about luxury brands, as luxury was the segment chosen to verify the country of origin effect.

\subsection{LUXURY BRANDS AND THE LUXURY PURCHASE DECISION}

The luxury market is a high added value industry based on high brand assets (KIM; $\mathrm{KO}, 2012)$. Its growth is exponential, which is evidenced by the aggregate net revenues of luxury goods belonging to the 100 largest luxury companies in 2015: 214.2 trillion USD, equivalent to an average of 2.1 billion USD per company (DELOITTE, 2015). We can observe this expansion, above all, in surges of demand in emerging countries, such as Brazil, Russia, India, and China (KAPFERER, 2014).

The word luxury means overload, excess, beyond necessity (KAPFERER, 2014). The word has connotations of grandeur and dissolution, excess and sumptuousness, embracing also material meanings, concrete (great expenses, costly) and intangible aspects (superfluous, pleasure, ostentation) (PIZZINATTO et al., 2014). A common use of it refers to an indulgence in which something is rarely experienced because it is expensive or hardly accessible, which is linked to exclusivity and status (JACKSON, 2004).

Therefore, from a product point of view, luxury brands are characterized by exclusivity, high prices, image, and status (JACKSON, 2004). Fionda and Moore (2009) emphasize high quality, high transaction value, uniqueness, exclusivity and perfection as luxury brand features; however, they point out that the consumption of luxury brands is related to a symbolic value, which operates on an individual and collective level. From the economic point of view, the luxury brand refers to the object whose price-quality ratio is the highest on the market, so what counts is not the absolute price, but the difference in price in relation to products with comparable functionalities (KAPFERER, 2003).

The luxury brand should evoke uniqueness and exclusivity through high prices, quality and controlled distribution (JIN, 2012). When a consumer chooses it, they are taking into account utilitarian, emotional, and symbolic dimensions (GODEY et al., 2012). Their value perceptions are therefore related to financial (price), functional (usability, quality, singularity), individual (personal identity/self-concept, hedonic and material value), and social (prestige, status) perceptions (HENNINGS et. al, 2012).

This means that the purchase of a luxury brand is related to several attributes such as quality, exclusivity, high price, inspirational brand, which reflects the amount of information that the consumer seeks, in addition to the country of origin, when evaluating a luxury brand. That corroborates the second hypothesis that the country of origin influence in the evaluation of luxury brands is weaker in the presence of other extrinsic cues: brand, price, warranty and store.

The importance of price and brand, among extrinsic information cues, is evident. The premium price is inherent in the luxury brand concept presented earlier. In addition, the luxury brand carries a strong symbolic and emotional load represented by the status that luxury consumption generates and, according to Kim and Ko (2012), related to the legacy and the building of trustworthy relationships with the consumer. Thus, based on these characteristics of the luxury brand, and considering the luxury perfume category addressed in this study, we are able to formulate the third hypothesis of the research: 


\section{Hypothesis 3. Price AND BRAND ARE THE MOST IMPORTANT EXTRINSIC CUES IN THE BRAND EVALUATION OF LUXURY PERFUMES.}

Furthermore, according to Jackson (2004), the main categories that encompass luxury brands are: (1) fashion and leather goods; (2) watches and jewelry; (3) perfumes and cosmetics; (4) wines and spirits drinks; and (5) other retails and companies (usually related to art). Another division can be considered: (1) clothing and footwear; (2) bags and accessories; (3) cosmetics and fragrances; (4) jewelry; and (5) other luxury items (DELOITTE, 2015). The category chosen for this study is perfumes.

Company groups that operate around the world manage these categories; however, they are usually from developed countries (DELOITTE, 2015). The scope of the segment and its categories is therefore global and, according to Kapferer (2014), with a focus on retail and commitment to expand brands into reach and diversity.

Thus, luxury international businesses and their brands are challenged by the identification and satisfaction of needs and desires of the global market segment (HENNIGS et al., 2012), making the country of origin a relevant subject to be verified in this context. Next, we present the methodological procedures used in this research.

\section{METHOD}

This study is characterized as descriptive, since it is structured with hypotheses or declared research questions (MALHOTRA, 2012; COOPER; SCHINDLER, 2011). It is also quantitative, whose main methodological characteristics are the validation of facts, estimates and relationships; representativeness through large samples; and statistical analysis of the data (HAIR et al., 2010).

For the development of the research, the following steps were taken: (i) selection of luxury brands to be analyzed; (ii) delimitation of the research variables; (iii) data collection and samples; (iv) data analysis using descriptive statistics of the sample, Kruskall Wallis tests to verify the differences between the groups of chosen brands and non-parametric tests to examine the differences between the research variables.

\subsection{SELECTED LUXURY BRANDS}

In order to achieve the research objective, we selected three well-known luxury perfume brands from three different countries: Ralph Lauren (United States), Chanel (France), and Hugo Boss (Germany), and the origin of the brands was not identified to the research participants. These brands are classified and are part of the report of global powers of luxury goods, elaborated by Delloite (2015) and taken as reference in this study. This report identifies the 100 largest luxury goods companies in the world based on the publicly available data, making a distinction by sectors, including cosmetics and fragrances, which is the focus of this research.

Firstly, we chose only one product category to control possible variations of the intrinsic product information cue, which would imply different consumer evaluations. According to the literature, consumers make rational product choices by comparing and contrasting their various attributes, and the country of origin effect then varies between different product categories. Therefore, by selecting products of the same category, the evaluation of the same intrinsic cues by consumers is guaranteed.

Secondly, the perfume category was chosen because it represents $11 \%$ of the 100 largest luxury companies in the world and $16.1 \%$ of the sales of these companies according to Delloite (2015). In addition, the perfume industry was the one with the most well-known brand names for Brazilians, the target of the research, strengthening its choice after a pretest with students. 
Third, we selected the three brands through two criteria: (1) different country of origin and (2) recognition by respondents in the pre-test considering a group of luxury perfume brands. It is worth mentioning that, in order to maintain and protect its customers, the luxury brand creates barriers to entry through price, selective and exclusive distribution, or even the aesthetics of the product and, for that reason, the luxury brand must be known and desired by all, but not attainable by the majority: its notoriety must be greater than its penetration (KAPFERER, 2003) and thus the recognition by the respondents is a key factor.

\subsection{RESEARCH VARIABLES}

The research variables helped to answer the hypotheses. In this study, they referred mainly to the extrinsic cues related to luxury perfumes: brand, price, country of origin, warranty and store (which sells the brand).

We also included as variable an intrinsic cue related to luxury perfume, the fragrance, in order to only show the importance of this variable in relation to the extrinsic ones, and whether there is a similar evaluation of this variable since it is a single category of product. Thus, we used this variable as a control of the intrinsic variables.

Finally, we used demographic variables such as age, gender, income, including one referring to the possible purchase of the product and a variable seeking to verify whether there is a recognition of which country the perfume brand evaluated is from.

\subsection{SAMPLE AND DATA COLleCtion}

The authors collected a non-probabilistic and convenience sample composed by undergraduate and graduate students living in Brazil, more specifically in Ribeirão Preto/ SP. Convenience sampling is used by many studies in this country of origin area and it is permissible to verify theories (ROTH; DIAMANTOPOULOS, 2009). The student segment is also quite frequent in country image field and country of origin surveys.

Data were collected through a questionnaire composed of questions related to the variables of the research. This questionnaire aimed to evaluate the country of origin effect as one of the extrinsic cues of consumer's luxury brand purchase decision. Therefore, the questionnaire was built to initially present a perfume image among one of the three brands chosen for the study: Ralph Lauren, Chanel, and Hugo Boss.

The interviewee was then presented to one of the three brands and after confirming that he/she recognized the brand, he/she judged the 5 extrinsic variables of purchase decision (Brand, Price, Warranty, Store and Country of origin) as well as the intrinsic variable Fragrance, placed as control of the intrinsic variables. All questions were constructed based on the 5-point interval scale, in which 1 represented "not important" and 5, "very important." This operationalization was based on the Godey et al. (2012) scale, which investigated luxury and non-luxury brands considering extrinsic and intrinsic attributes (design, price, brand, warranty, country of origin, and advertisement). The sentences of the scale used in this baseline study were subjected to a main component analysis with the Varimax rotation, resulting in an internal reliability of the measurement by Crombach's Alpha of 0.715, showing internal consistency.

The questionnaire also contained questions regarding demographic variables, as well as two questions to verify if the respondent knew the country of origin of the luxury brand considered and if they had already purchased the featured brand. It is worth mentioning that the brand evaluated by each respondent was chosen randomly among the three brands available.

The content validity was verified by a group of professors and graduate students, who assisted with their observations (mainly composing and altering the previous version of the questionnaire), seeking theoretical consistency and the best response format for the items in 
BBR

15,4

the instrument collection. Then, we conducted a pre-test with undergraduate and graduate students that allowed verifying the applicability of the questionnaire and to perform a greater refinement of the items.

The final questionnaire was made available by electronic means and submitted to undergraduate and graduate students through the contacts of the departments of the units surveyed. We obtained a total of 373 responses, of which 329 were valid: 104 were responses on Ralph Lauren, 130 on Chanel, and 95 on Hugo Boss. The results were tabulated and analyzed using SPSS statistical software.

\subsection{Data Analysis}

Data analysis initially consisted of a descriptive analysis of the sample profile: age group, gender, income, whether the respondent had already purchased the brand, and whether or not he or she knew the country of origin of the brand.

Then, we performed the Kruskal-Wallis tests with the extrinsic and intrinsic variables and considering the three groups of brands (Ralph Lauren, Chanel, and Hugo Boss) in order to verify if there are differences in the evaluation of different perfumes in terms of brand, price, warranty, store, country of origin and fragrance, allowing the verification of hypothesis 1 . Finally, we performed non-parametric tests between the extrinsic variables and descriptive statistics (mean and standard deviation) to verify hypotheses 2 and 3 . Although the sample is non-probabilistic, these tests are valid, since we only intend to verify a theory, and we do not propose generalizing the results.

\section{RESULTS}

We divided the results into three procedures: analysis of the sample profile; Kruskal Wallis test; and Mann-Whitney test and descriptive statistics.

\subsection{Sample Profile}

The sample consisted of 329 students, of whom the majority were women (181), followed by 132 men and 16 people who did not respond. The age of these students was mainly between 18 and 25 years. As for income, the majority was in a group of incomes between 4,100.00 BRL and 12,300.00 BRL. These data are detailed in Table 1.

Table 1. Demographic Aspects of the Sample

\begin{tabular}{llc}
\hline & Demographic Feature & Number of Respondents (Percentage) \\
\hline Gender & Female & $181(55.02 \%)$ \\
& Male & $132(40.12 \%)$ \\
& They did not answer & $16(4.86 \%)$ \\
\hline Age & Under 18 years old & $5(1.52 \%)$ \\
& From 18 to 25 years old & $197(59.88 \%)$ \\
& From 26 to 35 years old & $91(27.65 \%)$ \\
& From 35 to 50 years old & $19(5.77 \%)$ \\
& Over 50 years old & $3(0.91 \%)$ \\
& They did not answer & $14(4.26 \%)$ \\
\hline From 820.00 BRL to 2,460.00 BRL & $52(15.81 \%)$ \\
& From 2,460.00 BRL to 4,100.00 BRL & $72(21.88 \%)$ \\
& From 4,100.00 BRL to 12,300.00 BRL & $145(44.07 \%)$ \\
& Over 12,300.00 BRL & $46(13.98 \%)$ \\
& They did not answer & $14(4.26 \%)$ \\
\hline
\end{tabular}


Of these students, $207(62.92 \%)$ had already purchased the perfume brand from the questionnaire to which they replied, while 122 (37.08\%) had not purchased the brand. Still, of the 329 total respondents, $159(48.33 \%)$ knew the country of origin of the brand of perfume while $170(51.67 \%)$ did not respond correctly about the country of origin of the brand. These results may be an indication that, perhaps, the country of origin is not so important in the assessment of these consumers, since most of the students did not even know the country of origin of the brand that they were judging. We investigated this was more thoroughly in the following items, with the verification of the research hypothesis.

\subsection{Kruskal-Walluis TeSt}

We selected the Kruskal-Wallis test after normality tests with the variables. Thus, we conducted the Kolmogorov-Smirnov and Shapiro-Wilk tests, resulting in p-values lower than 0.01 for some of the extrinsic and intrinsic variables considered (which would corroborate the rejection of the hypothesis that the data have a normal distribution), and at $p$-values greater than 0.01 , indicating normality. The absence of a normal distribution in all variables implied the use of a nonparametric statistic (Kruskal-Wallis test) for the standardization and comparison of the results, which are exposed in Table 2.

Table 2. Kruskall-Wallis test for each variable

\begin{tabular}{lcccccc}
\hline & Brand & Price & $\begin{array}{c}\text { Country of } \\
\text { origin }\end{array}$ & Warranty & Store & Fragrance \\
\hline Chi-square & 0.039 & 0.967 & 3.840 & 5.115 & 3.570 & 2.035 \\
DF & 2 & 2 & 2 & 2 & 2 & 2 \\
Asymptotic Significance & 0.981 & 0.616 & 0.147 & 0.078 & 0.168 & 0.361 \\
\hline
\end{tabular}

According to the table above, there was no statistical evidence to state that there are significant differences between the distributions of each variable (brand, price, country of origin, warranty, store, fragrance) when considering three different groups of brands (Ralph Lauren, Chanel and Hugo Boss), since the p-values found were high (above 0.01 and 0.05). Thus, it was not possible to reject the null hypothesis of the test that the distributions are similar.

This result indicated that the three groups of brands of luxury perfume were evaluated in a similar way in all categories considered, giving support, therefore, to hypothesis 1 of the research that the differences between the evaluations of attributes of luxury brands of a same category will not be significant, since they evaluate the same set of intrinsic and extrinsic cues to assess the same product type (in this case, the luxury perfumes). In order to verify the remaining two hypotheses, we performed Mann-Whitney tests and descriptive statistics.

\subsection{Mann-Whitney Test and Descriptive Statistics}

Considering that Ralph Lauren, Chanel, and Hugo Boss perfumes were evaluated in a similar way, the samples of the three brands were condensed into a single luxury perfume group to evaluate extrinsic cues and perform non-parametric tests (Mann Whitney).

These tests examined the null hypothesis that the medians are equal. They were performed because the normality of the data was not found in all extrinsic variables (brand, price, country of origin, warranty and store), which presented p-values lower than 0.01 . The results of these tests, comparing the extrinsic cue pairs, are shown in Table 3.

According to Table 3, there were differences of medians between the majority of groups, except when it was considered warranty and store, whose p-value was high, indicating that the medians of the groups are the same. 
BBR

15,4

358

Table 3. Mann Whitney tests and significance

\begin{tabular}{ccccc}
\hline $\begin{array}{c}\text { Test value } \\
\text { (Significance) }\end{array}$ & Brand & Price & Country of origin & Warranty \\
\hline Price & $-4.956(0.000)$ & & & \\
Country of origin & $-11.570(0.000)$ & $-15.060(0.000)$ & & \\
Warranty & $-5.423(0.000)$ & $-9.552486(0.000)$ & $-5.836(0.000)$ & $-0.880(0.379)$ \\
Store & $-7.035(0.000)$ & $-11.510(0.000)$ & $-5.659(0.000)$ & \\
\hline
\end{tabular}

Thus, this table showed differences between almost all extrinsic cues groups, but did not reveal which information was the most important in consumer's assessments. For this, the descriptive statistics of mean and standard deviation, shown in Table 4, were necessary.

Firstly, Table 4 showed that the fragrance attribute was the highest mean, and this meant that the intrinsic cue was the most important at the choosing time of luxury brand (overall mean of 4.72), agreeing with Olson and Jocoby (1972) and Goldey et al. (2012) who claim that intrinsic cue has a more powerful effect than extrinsic cue in shaping quality judgments and consumer opinions. However, this importance is not so prominent in this study since we used the variable of fragrance only as a control. In addition, consumers may want to appear rational, and so it would be logical to point to fragrance as the most relevant factor, even though most of them $(62.02 \%)$ may not purchase the brand and may not be able to assess the perfume fragrance in question. At this point, the most appropriate method would be an experiment, but this is not deepened here, since the focus of the research is on the extrinsic variables to the perfumes evaluated.

Table 4. Descriptive Statistics

\begin{tabular}{|c|c|c|c|c|}
\hline \multicolumn{2}{|l|}{ Variable } & $\mathrm{N}$ & Mean & $\begin{array}{l}\text { Standard } \\
\text { Deviation }\end{array}$ \\
\hline \multirow[t]{4}{*}{ Brand } & Ralph Lauren & 104 & 3.52 & 1.254 \\
\hline & Chanel & 130 & 3.45 & 1.387 \\
\hline & Hugo Boss & 95 & 3.47 & 1.279 \\
\hline & Total & 329 & 3.48 & 1.311 \\
\hline \multirow[t]{4}{*}{ Price } & Ralph Lauren & 104 & 3.99 & 1.219 \\
\hline & Chanel & 130 & 3.90 & 1.160 \\
\hline & Hugo Boss & 95 & 4.02 & 1.101 \\
\hline & Total & 329 & 3.96 & 1.160 \\
\hline \multirow[t]{4}{*}{ Country of origin } & Ralph Lauren & 104 & 2.00 & 1.207 \\
\hline & Chanel & 130 & 2.34 & 1.367 \\
\hline & Hugo Boss & 95 & 2.08 & 1.269 \\
\hline & Total & 329 & 2.16 & 1.295 \\
\hline \multirow[t]{4}{*}{ Warranty } & Ralph Lauren & 104 & 2.80 & 1.523 \\
\hline & Chanel & 130 & 3.05 & 1.430 \\
\hline & Hugo Boss & 95 & 2.61 & 1.559 \\
\hline & Total & 329 & 2.84 & 1.504 \\
\hline \multirow[t]{4}{*}{ Store } & Ralph Lauren & 104 & 2,54 & 1,314 \\
\hline & Chanel & 130 & 2.85 & 1.347 \\
\hline & Hugo Boss & 95 & 2.78 & 1.306 \\
\hline & Total & 329 & 2.73 & 1.328 \\
\hline \multirow[t]{4}{*}{ Fragrance } & Ralph Lauren & 104 & 4.66 & 0.920 \\
\hline & Chanel & 130 & 4.74 & 0.721 \\
\hline & Hugo Boss & 95 & 4.75 & 0.911 \\
\hline & Total & 329 & 4.72 & 0.842 \\
\hline
\end{tabular}


Considering only the extrinsic variables (price, brand, country of origin, warranty and store) present in Table 4 and which are focus of the study, we were able to verify that the overall mean of country of origin relevance for consumers when deciding to purchase was the lowest (2.16) among all extrinsic cues considered, indicating that the country of origin effect was weakened in the presence of other external information as predicted by Kabadayi and Lerman (2011) and highlighted in studies with luxury brands: Godey et al. (2012), Pizzzinatto et al. (2014), Ozretic-Dosen and Previsic (2014), and Schultz and Jain (2015). Thus, hypothesis 2 , that the importance of the country of origin in the evaluation of luxury perfume brands is smaller in the presence of the other extrinsic cues (brand, price, warranty and store) was confirmed. In addition to that, if the means of country-of-origin of each luxury brands are observed individually, Chanel is the one with a slightly higher mean (2.85), and this may be related to the country of origin being relatively easy to infer by the name of the brand, which reminds French and the fact that the word "Paris" is present in the perfume. However, this score is still very low when compared to the others referring to extrinsic cues.

Finally, by observing the other extrinsic variables, we observed that the variable price is the most important, with an overall mean of 3.96 , followed by brand, with an mean of 3.48, which is also quite high. These results confirm hypothesis 3 of the research, of which price and brand are the most important extrinsic cues in the perfume luxury brands evaluation. They also corroborate the literature, which states that the luxury brand is linked primarily to attributes of quality, exclusivity, high price, inspirational brand (JACKSON, 2004; FIONDA; MOORE; 2009; JIN, 2012; KAPFERER, 2014).

\section{CONCLUSIONS}

Considering that country of origin research still presents many controversies and difficulties in measuring the country of origin effect, this research aimed to verify the extent of this effect in the decision to consume luxury brands when evaluating a series of other cues together with the country of origin such as brand, price, warranty and store. For this purpose, we conducted a study with Brazilian students considering three brands of luxury perfumes from three different countries: Ralph Lauren, Chanel, and Hugo Boss.

This analysis presented that the country of origin has little importance when purchasing luxury brand perfumes, corroborating with results from previous studies. More specifically, there were no differences between the perfumes evaluations, and these evaluations showed that the country of origin is the least important information for consumers when purchasing a luxury perfume. The most important extrinsic cues considered by them in the purchase decision are price and brand.

From the managerial point of view, these results point out that brand managers can invest their efforts in strategies related to the price and brand of the product, since the country of origin is not important when purchasing a luxury perfume. It does not seem necessary to emphasize the country of origin in the strategies, since luxury brands are global and strong, and these brands weigh heavily on the decision along with the price.

In addition, considering the theoretical perspective, this study contributed to the advancement in the literature of the country of origin, verifying this effect in the context of luxury and emerging countries, which are increasingly representative in the demand for luxury.

However, this research has some limitations. First, in this examination we analyzed only the category of luxury perfumes. Other categories of luxury brands can be investigated in future studies. The analysis of these perfume brands was carried out from the perspective of Brazilians, and can be replicated in other cultures, in which the most important criteria may change among consumers. 
BBR

15,4

Second, we used a non-probabilistic and convenience sample with undergraduate and graduate students. This type of sampling prevents the generalization of results; so other population segments should be taken into account in future research to strengthen the results obtained.

Students may also not be the ideal audience to evaluate a luxury product, since (i) they have low purchasing power and perhaps for this reason the price has also been of great importance, thus being another reason to investigate the country of origin effect in other segments, (ii) in most cases, they did not recognize the country of origin of the sample, and in this sense, future studies can compare the perspectives of those who recognized and those who did not identify the country of origin.

Finally, there are other moderators that can increase or decrease the country of origin effect present in the literature and that were not considered in this study: the individual characteristics of the consumers and the features of the producing country of the product.

The first ones encompass demographic factors such as age, gender, income, education, as well as motivation, lifestyle, familiarity with the product and the brand, degree of involvement with the product, personal values, fluency in the language of the country, and ethnocentrism (GIRALDI; IKEDA, 2009). The second ones are related to the economic, historical, political and cultural characteristics of the country of origin of the products (PISHARODI; PARAMESWARAN, 1992).

These moderators and the extrinsic and intrinsic cues of the products can be explored together in future studies to verify the magnitude of the country of origin effect.

\section{REFERENCES}

AHMED, Z.; ANANG, R.; OTHMAN, N.; SAMBASIVAN, M. To purchase or not to purchase US products: role of religiosity, animosity, and ethno-centrism among Malaysian consumers. Journal of Services Marketing, v. 27, n. 7, p. 551-563, 2013.

AHMED, Z. U.; JOHNSON, J. P.; YANG, X. FATT, C. K.; TENG, H. S.; BOON, L. C. Does country of origin matter for low-involvement products? International Marketing Review, v. 21, n. 1, p. 102-120, 2004.

ANDINA, C. GABRIELA, C.; ROXANA-DENISA, S. Country-of-Origin Effects on Perceived Brand Positioning. Procedia Economics and Finance, v. 23, p.422-427, 2015.

APIL, A. R.; KAYNAK, E. Georgian consumers' evaluation of products sourced from European Union member countries: Country of origin impact. International Journal of Commerce and Management, v. 20, n. 2, p. 167-187, 2010.

AYROSA, E. A. T. Imagem de País: Uma Escala Para Avaliar Atitudes Relativas a Países. In: XXII Encontro Anual da ANPAD, 1998, Foz do Iguaçu. Anais... Foz do Iguaçu, 1998. CD-ROOM.

BHASKARAN, S.; SUKUMARAN, N. Contextual and methodological issues in COO studies. Marketing Intelligence \& Planning, v.25, n.1, p. 66-81, 2007.

BILKEY, W. J.; NES, E. Country-of-origin Effects on Product Evaluations. Journal of International Business Studies, v. 13, p. 89-99, 1982.

BLOEMER, J; BRIJS, K.; KASPER, H. The CoO-ELM model A theoretical framework for the cognitive processes underlying country of origin-effects. European Journal of Marketing, v. 43, n. 1/2, p. 62-89, 2009.

BRIJS, K.; BLOEMER, J.; KASPER, H. Country-image discourse model: unraveling meaning, structure, and function of country images. Journal of Business Research, v. 64, n. 12, p. 1259-1269, 2011.

CASTRO, R. M.; GIRALDI, J. M. E. Processo de desenvolvimento e gestão de marca -país: um estudo sobre a Marca Brasil. Revista Turismo Visão e Ação - Eletrônica, Vale do Itajaí, v.14, n.2, p.164-183, 2012.

CHAO, P.; RAJENDRAN, K. N. Consumer Profiles and Perceptions: Country-of-origin

Effects. International Marketing Review, v. 10, n.2, p. 22-39, 1993.

COOPER, D. R.; SCHINDLER, P. S. Métodos de pesquisa em administração. 10. ed. Porto Alegre: Bookman, 2011.

D'ASTOUS, A.; AHMED, S. A. The importance of country images in the formation of consumer product perceptions. International Marketing Review, v. 16 n. 2, p. 108-125, 1999.

DEB, M.; CHAUDHURI, H. R. Assessing the ethnocentric tendencies of diferent age-cohorts in an emerging market. Journal of Indian Business Research, v. 4, n. 4, p. 244-268, 2012. 
DELOITTE. Global Powers of Luxury Goods 2015. 2015. Disponível em: < http://www2.deloitte.com/ content/dam/Deloitte/global/Documents/Consumer-Business/gx-cb-global-power-of-luxury-web.pdf $>$. Acesso em: 29. Mai. 2016.

FIONDA; A. M.; MOORE, C. M. The anatomy of the luxury fashion brand. Brand Management,v.16, n. 5/6, p. 347-363, 2009.

GIRALDI, J. M. E.; CARVALHO, D. T. de. A imagem do Brasil no exterior e sua influência nas intenções de compra. RAC Eletrônica, v. 3, p. 22-40, 2009.

GIRALDI, J. M. E; IKEDA, A. A. . Personal values and the 'country-of-origin effect': the moderating role of consumers' demographics. International Journal of Consumer Studies, v. 33, p. 309-315, 2009.

GODEY, B.; PEDERZOLI, D.; AIELlO, G.; DONVITO, R.; CHAN, P.; OH, H.; SINGH, R.; SKOROBOGATYKH, I. I. ; TSUCHIYA, J. ; WEITZ, B. Brand and country-of-origin effect on consumers' decision to purchase luxury products. Journal of Business Research, v. 65, n. 10, p. 1461-1470, 2012.

HAIR, J.F.Jr; WOLFINBARGER, M.; ORTINAU, D.J.; BUSH, R.P. Fundamentos de pesquisa em marketing. Porto Alegre: Bookman, 2010.

HAM, V. P. Place branding: The state of the art. The Annals of the American Academy of Political and Social Science, v. 616, n.1, p. 126-149, 2008.

HANNA, S.; ROWLEY, J. An analysis of terminology use in place branding. Place branding and public diplomacy, v. 4, n.1, p.61-75, 2008.

HENNIGS, N.; WIEDMANN, K-P..; KLARMANN, C.; STREHLAU, S.; GODEY, B.; PEDERZOLI, D.; NEULINGER, A.; DAVE, K.; AIELLO, G.; DONVITO, R.; TARO, K.; TABORECKA-PETROVICOVA, J.; SANTOS, C. R.; JUNG, J.; OH, H. What is the Value of Luxury? A Cross-Cultural Consumer Perspective. Psychology and Marketing, v. 29, n. 12, p. 1018-1034, 2012.

HERZ, M. C.; DIAMANTOPOULOS, A. Country-Specific Associations Made

by Consumers: A Dual-Coding Theory Perspective. Journal of International Marketing, v. 21, n. 3, p. 95-121, 2013.

JACKSON,T. A comtemporary analysis of global luxury brands. In: A Case Study Approach. Burlington: Elsevier, 2004. p. 155-170. . International Retail Marketing:

JIN, S. A. The potential of social media for luxury brand management. Marketing

Intelligence \& Planning, v. 30, n. 7, p. $687-699,2012$.

KABADAYI, S.; LERMAN, S. Made in China but sold at FAO Schwarz: country-of-origin effect and trusting beliefs. International Marketing Review, v.28, n.1, p. 102-126, 2011.

KAPFERER, J. N. The artification of luxury: From artisans to artists. Business Horizons, v. 57, n. 3, p. 371$380,2014$.

KAPFERER, J. N. As marcas: capital da empresa- criar e desenvolver marcas fortes. 3 ed. Porto Alegre: Bookman, 2003.

KAYNAK, E; KUCKUKEMIROGLU, O.; HYDER, A. S. Consumers' country-of-origin (COO) perceptions of imported products in a homogenous less-developed country. European Journal of Marketing, Vol. 34 No. 9/10, p. 1221-1241, 2000.

KAVARATZIS, M.; HATCH, M. J. The dynamics of place brands: An identity-based approach to place branding theory. Marketing theory, v.13, n.1, 69-86, 2013.

KIM, A. J.; KO, E. Do social media marketing activities enhance customer equity? An empirical study of luxury fashion brand. Journal of Business Research, v. 65, n. 10, p. 1480-1486, 2012.

KOSCHATE-FISCHER, N.; DIAMANTOPOULOS, A.; OLDENKOTTE, K. Are Consumers Really Willing to Pay More for a Favorable Country Image? A Study of Country-of-Origin Effects on Willingness to Pay. Journal of International Marketing,v. 20, n. 1, p. 19-41, 2012.

KRUPKA, Z.; OZRETIC-DOSEN, D.; PREVISIC, J.Impact of Perceived Brand Name Origin on Fashion Brand's Perceived Luxury. Acta Polytechnica Hungarica, v. 11, n. 3, p. 153-166, 2014.

LAROCHE, M.; PAPADOPOULOS, N.; HESLOP, L. A.; MOURALI, M. The influence of country image structure on consumer evaluations of foreign products, International Marketing Review, v. 22, n. 1, p. 96$115,2005$.

MALHOTRA, N. Pesquisa de marketing: uma orientação aplicada. 6. ed. Porto Alegre: Bookman, 2012.

NAGASHIMA, A. A comparison of Japanese and US attitudes toward foreign products. Journal of Marketing, v.34, n.1, p.68-74, 1970.

OLSON, J.; JACOBY, J. Cue utilization in the quality perception process. In: SV- Proceedings of the Third Annual Conference of the Association for Consumer Research, eds. M. Venkastesan, Chicago, IL: Association for Consumer Research, p. 167-179, 1972. 
BBR

15,4

362

PAPPU, R.; QUESTER, P. G.; COOKSEY, R. W. Consumer-based brand equity: improving the measurementempirical evidence. Journal of Product \& Brand Management, v. 14, n. 3, p. 143-154, 2005.

PRENDERGAST, G. P.; TSANG, A. S. L.; CHAN, C.N. W. The interactive influence of country of origin of brand and product involvement on purchase intention. Journal of Consumer Marketing, v. 27, n. 2, p. 180-188, 2010.

PISHARODI, R. M.; PARAMESWARAN, R. Confirmatory factor analysis of a country-of-origin scale: Initial results. In John Sherry and Brian Sternthal (Eds.), Advances in Consumer Research, v. 19, p. 706714, 1992. Provo, UT: Association for Consumer Research, 1992.

PIZZINATTO, A. K.; PIZZINATTO, N. K.; LOPES, E. L.; GIULIANI, A. C.Efeito país de origem na avaliação de marcas de luxo: um estudo experimental. Revista Eletrônica de Negócios Internacionais, v. 9, n. 2, p. 94- 109, 2014.

SAMIEE, S. Advancing the country image construct - A commentary essay. Journal of Business Research, v. 63, n. 4 , p. $442-445,2010$.

SCHUKLA, P. Impact of interpersonal influences, brand origin and brand image on luxury purchase intentions: Measuring interfunctional interactions and a cross-national comparison. Journal of World Business, v. 46, n. 2, p. 242-252, 2011.

SCHULTZ, D.; JAIN, V. Exploring luxury brand country of origin impact on purchasing behaviors in India Asia-Pacific Journal of Business Administration, v. 7, n.3, p. 216 - 236, 2015.

USUNIER, J.C. Relevance in business research: the case of country-of-origin research in marketing. European Management Review, v. 3, n.1, p. 60-73, 2006.

USUNIER, J. C. The shift from manufacturing to brand origin: suggestions for improving COO relevance. International Marketing Review, v. 28, n. 5, p. 486-496, 2011.

VERLEGH, P. W. J.; STEENKAMP, J. B. E. M. A review and meta-analysis of country-of-origin research. Journal of Economic Psychology, v. 20, n. 5, p.521-546, 1999.

ZEUGNER-ROTH, K. P.; DIAMANTOPOULOS, A.Advancing the country image construct: Reply to Samiee's (2009) commentary. Journal of Business Research, v.63, n.4, p. 446-449, 2010.

We state there are no conflicts of interests. And all authors contributed to the paper construction. 